\title{
From past to present born global phenomenon: a thematic analysis ${ }^{1}$
}

\author{
Şayan Berber ${ }^{2}$, Mahmut Köle ${ }^{3}$, Mustafa Emre Taş̧̧ı ${ }^{4}$, Esin Can $^{5}$
}

\begin{abstract}
The purpose of this study is to investigate all related studies that have been published between the years of 1989-2015 in the area of the born global (BG) phenomenon that enumerates the firms which are becoming active in the international market arena by using the methodology of thematic analysis. From the Web of Science Core Collection, 198 articles have been included which have been examined in detail according to their distribution throughout the years, types, focused subjects, writers, institutions, publishing houses and countries. This study is critical as it analyzes the subject of BGs / international new ventures (INVs) with their ever-mounting number, and the effects in the global market during the past three decades by reviewing related research under a systemized thematic umbrella and its importance in regards to significant contributions by defining four thematic top-groups (organizational, sustainability, internationalization, research) with detailed subgroups.
\end{abstract}

Keywords: born global(s), international new ventures, global start-ups, instant internationals, instant exporters, early internationalizing firms.

JEL codes: M13, M16, M21.

\section{Introduction}

In recent years the increased number of BG firms in worldwide economies spread amongst diverse industries has drawn the attention of researchers. The objective of this study is to identify new studies from the early 1990s, especially those increasing after the 2000s which were parallel with the conceptualization

\footnotetext{
${ }^{1}$ Article received 6 December 2017, accepted 24 April 2018.

2 İstanbul Yeni Yüzyıl University, Vocational School, Department of International Trade, İstanbul, Turkey, sayan.berber@gmail.com.

${ }^{3}$ Ylldız Technical University, Faculty of Economic and Administrative Sciences, Business Administration, İstanbul, Turkey.

${ }^{4}$ İstanbul Commerce University, Faculty of Business, Department of Aviation Management, İstanbul, Turkey.

${ }^{5}$ Ylldız Technical University, Faculty of Economic and Administrative Sciences, Business Administration, İstanbul, Turkey.
} 
of BGs and thus to design a framework for thematic analysis. Studies that are related to early and instant internationalizing firms, have focused on international entrepreneurship (Rialp, Rialp, \& Knight, 2005; Keupp \& Gassman 2009; Jones, Coviello, \& Tang, 2011; Kiss, Danis, \& Cavusgil, 2012). These become prominent as they directly focus on BG firms as distinct from other studies and highlight the influential researchers, countries and schools.

Within the scope of this study the Web of Science Core Collection database has been used for the identification of related research. To define early and instant internationalizing firms, the term 'BGs' (Rennie, 1993; Cavusgil, 1994; Knight \& Cavusgil, 1996; Madsen \& Servais, 1997) and other related terms have been used to discover the area of related articles such as International New Ventures (McDougall, Shane, \& Oviatt, 1994; Oviatt \& McDougall, 1994, 1997), Global Start-ups (Oviatt \& McDougall, 1995; Hordes, Clancy, \& Baddaley; 1995), Instant Internationals (Fillis, 2001), Instant Exporters (McAuley, 1999), Early Internationalizing Firms (Rialp et al., 2005).

After thoroughly investigating the concept of BGs in its developmental progress within international business theory, the methodology has been refined to reach a better understanding by the categorization of themes. Selection criteria, the entering of descriptive information uncovered through data research, designation of thematic framework, and coding by three authors. This process gives birth to the thematic clarification in the area with four thematic top-groups (organizational, sustainability, internationalization, research), 17 main-theme, and 49 sub-theme bands.

Traditional internationalizing models support the idea that there is a staggered waiting time for firms wishing to join international markets which could be achieved only after a long-term learning process. Two of the most well-known traditional models which explain internationalization behaviours as a long-term learning process are the Uppsala Internationalization Model (Johanson \& Vahlne, 1977) and the Innovation Model (Bilkey \& Tesar, 1977; Cavusgil, 1980; Reid, 1981). These models illuminate all the stages on a path on which a firm embarks towards exportation from the initial joining of international markets until the end stage which is direct foreign investment (Cavusgil, Knight, \& Riesenberger, 2008).

As traditional models are not sufficient to define early and instant internationalizing firms, a new internationalization model was developed to fill any remaining gaps. The firms which are recognized as BGs are unconventionally distinguished from traditional internationalized firms and are firms seeking a competitive advantage by using their resources and outputs to transform themselves into an international firm within a short time span (Oviatt \& McDougall, 1994).

In the literature three main criteria are mentioned to define BG firms. The first criterion establishes that these firms are small and medium size enterprises (Rennie, 1993; Knight \& Cavusgil, 1996; Knight, 1997). The second 
criterion designates the time period from the establishment of the enterprise to the entry into international markets. There is no fully agreed time period for this process but the most common viewpoint is three years (Rennie, 1993; Knight \& Cavusgil, 1996; Knight, 1997). To be a BG firm the third criterion is the share of exports in the total sales of a firm. The common view for this is $25 \%$ (Rennie, 1993, p. 46; Knight \& Cavusgil, 1996, p. 12; Knight, 1997, p. 2). In addition to these criteria the export ratio in sales should be continuous and all the aforementioned criteria should be included for acceptance as a BG firm.

The occurrence of BG firms in international literature has been explained by factors such as; the increased role of niche markets in advanced economies, the development of micro processors making small scale production more efficient, evolving communication technologies creating easy opportunities for crossborder transactions, the elasticity advantage of small and medium size enterprises for satisfying the needs of customers, the likely possibility to send information and technology to a wide variety of enterprises in a global world and the ease of collaboration with strategic alliances throughout global networks (Cavusgil, 1994, p. 18; Knight \& Cavusgil, 1996, pp. 21-22; Knight, 1997, pp. 5-9; Bell, McNaughton \& Young, 2001, p. 176).

The rest of the paper is structured as follows. Section 1 deals with the methodology used. It tracks standard approaches used in the literature. Section 2 is devoted to the presentation and analyses of results. The last section presents discussion and conclusions.

\section{Method}

To provide a comprehensive review a similar methodology as demonstrated in previous influential articles was used (Jones, Coviello, \& Tang, 2011; De Clercq, Sapienza, Yavuz, \& Zhou, 2012; Keupp \& Gassmann, 2009). The content of the study is based on the ISI-Web of Science Core Collection online database. Not only "Top-tier" entrepreneurship or management journals but covering even more journals thereby enlarging the scope and perspective to strengthen the generalization of the findings. In addition peer-reviewed articles have been included to validate the findings (Jones et al., 2011; Podsakoff, Mackenzie, Bachrach, \& Podsakoff, 2005). The article types have been narrowed down to include those of empirical, conceptual and review research types to demonstrate contrast whilst excluding editorials, commentaries and case studies published for teaching purposes to focus on the main topic of the subject. In contradistinction to some of the studies (De Clercq et al., 2012), review studies have been included to enrich the research by interpolating those specifically focused reviews to the research cluster. 
The articles between the years 1989-2015 have been fact checked according to their titles, keywords and abstracts depending on the need to discover related terms and concepts. A large scale research has been carried out to discover synonyms and similar terms. Synonymous are words listed in the research procedure.

After a comprehensive study of the ISI-Web of Science Core Collection, 297 studies were read/checked in detail according to their abstracts and keywords by three reviewers of the study. During this process unrelated subjects have been eliminated (e.g., very specific studies that have focused on the internationalization of SMEs or gradual internationalization). After the elimination process the number of remaining articles was 198. Thematic and other analyses have been executed throughout these 198 articles. Of those articles 167 are empirical, 25 are conceptual and 6 are review studies.

Theme identification and coding procedures have been applied to allow for a thematic analysis on the database set. For this reason all the conceptual review has been checked extensively and the most common terms have been selected in the field of International Entrepreneurship (IE). After defining the themesand by adopting a similar method of inquiry utilized in previous thematic studies (Jones et al., 2011; De Clercq et al., 2012), three researchers checked the related studies and coded them. As a next step coded themes were compared by researchers and afterwards combined to establish a common consensus to define themes.

In addition to the thematic analysis a complementary statistical analysis was carried out to extend the findings by determining the authors who contributed the most, universities and trends during these years. Descriptive information of the research data include the author, author's institution, author's institution's country, journal name, publication year and keywords.

Methodological procedures for research data (adapted from Jones et al., 2011) took the following steps:

1. Criteria for investigation:

a) BGs and terms have the same meaning,

b) peer-reviewed journal articles only,

c) empirical AND conceptual AND review articles.

2. Exclusion criteria:

a) research published in books and conference proceedings,

b) editorials and commentaries,

c) case studies published for teaching purposes only,

d) articles unavailable electronically.

3. Search method and scope:

a) full search of articles relevant to research keywords across academic journals indexed in the ISI Web of Science core collection, from 1989 to 2015,

b) keywords:

i. Born Global(s) (Knight \& Cavusgil, 2004), 
ii. International New Venture(s) (Oviatt \& McDougall, 1994),

iii. Early Internationalization (Sapienza, Autio, George, \& Zahra, 2006),

iv. Global Start-ups (Yeoh, 2000),

v. Instant Internationals/Internationalization (Preece, Miles, \& Baetz, 1999),

vi. Instant Exporters (McAuley, 1999),

vii. Early Internationalizing Firms (Rialp et al., 2005),

viii. Early exporters (Gallego \& Casillas, 2014),

c) manual reading/checking abstract and keywords of the articles in the research database by three reviewers based on fit within defined search parameters $(n=297)$,

d) eliminating irrelevant papers (e.g., papers related only to SME internationalizations or gradual internationalization),

e) final sample $(n=198)$.

4. Procedures for data interpretation and thematic analysis:

a) data organization

i. gather all selected articles in a logical order,

ii. design a basic structure on a defined table to create a comparison base,

b) theme identification and coding

i. identify main themes used in IE field and coding them by:

- organizational themes,

- sustainability themes,

- internationalization themes,

- research themes.

c) entering descriptive information of research data

i. author,

ii. author institution,

iii. author's institution's country,

iv. journal,

v. publication year,

vi. keywords,

vii. article theme(s).

\section{Results}

\subsection{Thematic analysis}

Mapping of the thematic analysis as shown in Figure 1 is important and valuable to display the output of the study.

To see the overall results of the analysis and to clarify the categories listed in the following sections. 


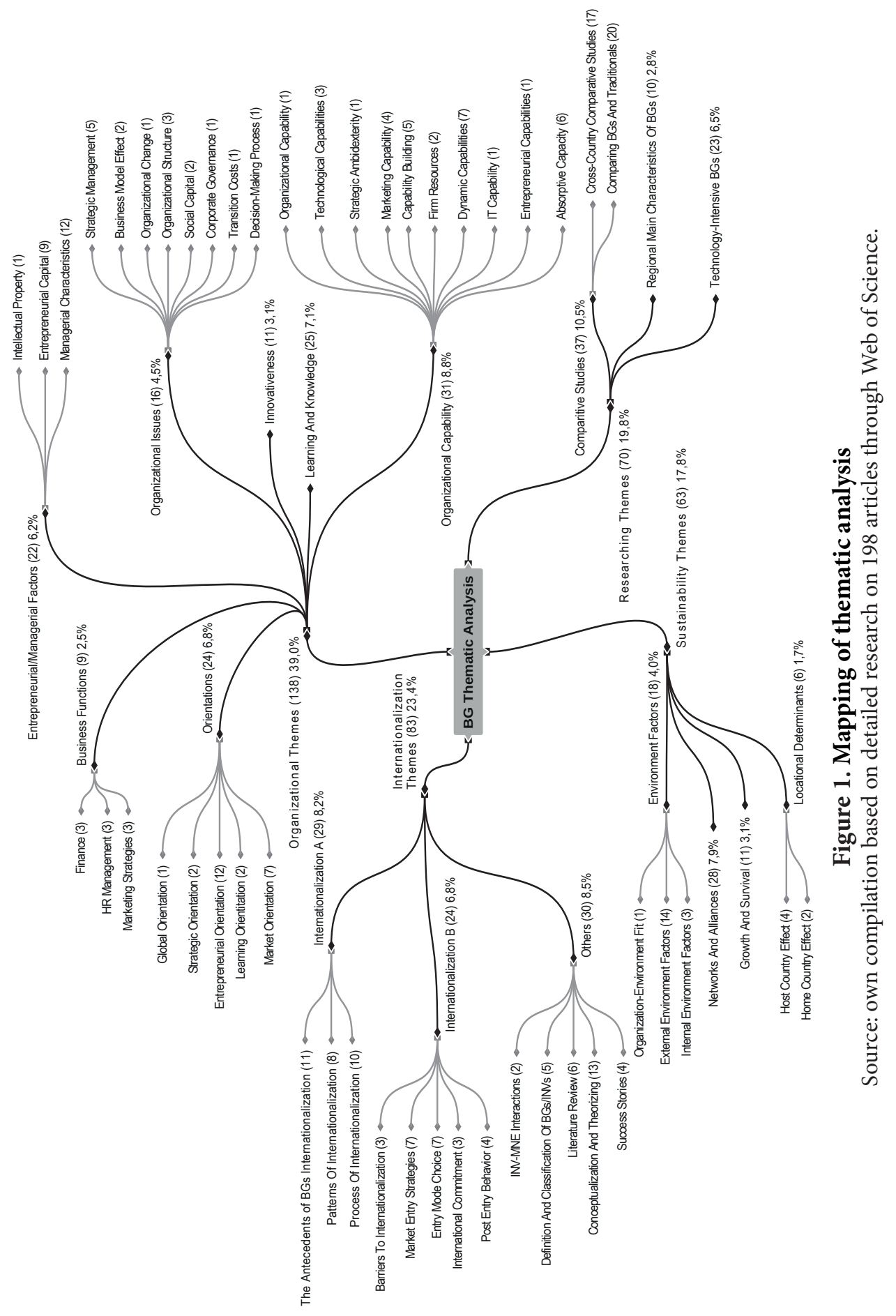




\subsubsection{Organizational themes}

Organizational themes are the most substantial groups between the four thematic top-groups and 39\% of the studies were executed in this area. It is critical to note that $65 \%$ of those studies have been researched in the last five years which illustrates the fact that organizational themes are the main stream for those researchers focusing on the BG field. It is a fact that BGs which could be viewed as an accelerated model of internationalization processes are a highly appealing area and organizational themes focus on the key factors of such an important and successful process of BG entities. In essence organizational themes are the main aspects of the organization which determine its capabilities, how the orientation is performed, under which entrepreneurial conditions, by structure type, related to the level of change sensitivity, by decision making models, using the power of innovativeness and how business functions are being carried out in an organization. Accordingly, under these investigational frameworks, themes which are listed in descending order by the number of studies are; organizational capability, learning and knowledge, orientations, entrepreneurial/managerial factors, organizational issues, innovativeness, business functions.

Organizational capability as a main-theme band highlights the capabilities of the BG entities in various areas supported by 31 articles $^{6}$ in which $8.8 \%$ of all research conducted lies within this band. As a sub-theme band marketing capability is foreseen as a direction towards the recognized value of the foreign market information [Knight et al., 2004; Evers et al., 2012; Ripolles \& Blesa, 2012; Zhou et al., 2012], capability building is based on the hunt for growth opportunities by being effective [Zhang \& Dodgson, 2007; Khavul, 2010b; Prashantham \& Dhanaraj, 2010; Evers et al., 2012; Abidi, 2015], the term firm sources could be defined as the essence of power and strengths originating from the mix of all resources [Schwens \& Kabst, 2011], dynamic capabilities focus on the deliberate management of dynamic competencies in regards to competition [Mort \& Weerawardena, 2006; Weerawardena et al., 2007; Voudouris et al., 2011; Khalid \& Larimo, 2012; Ripolles et al., 2012; Monferrer et al., 2015b], IT capability is a performance increasing factor on the entity [Zhang \& Sarker, 2013], strategic ambidexterity is causing firms to carry out inherently paradoxical strategies that embody and manifest two main strategic objectives [Han \& Celly, 2008], entrepreneurial capabilities come from from the founding of the firm to the entrepreneur's previous experience and their existing networks [Karra et al., 2008], and technological capabilities are the base framework which emphasizes the importance of accumulating both aspects of knowledge - information and know-how - in order to develop expertise and innovation [Knight et al., 2004; Efrat \& Shoham, 2011; Kim et al., 2011], absorptive capacity makes it possible for firms to search for and exploit technology and market opportu-

\footnotetext{
${ }^{6}$ References in square brackets are available from the authors upon request.
} 
nities in the local and foreign market by recognizing the value of new, external information by assimilation and application of it for commercial purposes [Welbourne \& De Cieri, 2001; Park, 2005; Freeman et al., 2010; Monferrer et al., 2015a; Prashantham et al., 2015], organizational capability is an overall usage of capabilities at a level resulting in the exceptionally rapid advancement of their globalization [Laanti et al., 2007].

Learning and knowledge as another main-theme band provides a base on how to accomplish all processes through the rapid acceleration of the steps of transformation into a BG entity. Intrinsically this theme is the first theme in a field in which researchers sought to seek and understand the formation of BGs hence 25 articles in which $7.1 \%$ of all research has been related to this theme. Interactive effects of learning could be introduced by congenital learning, international experience, experiential learning and inter-organizational acquirements from customers, suppliers, investors, etc. It is a capability building process inevitably touching several aspects and learning from unexpected experiences whilst facing rapidly changing phases of growth [De Clercq et al., 2008; Bruneel et al., 2010; Freeman et al., 2010; Carvalho et al., 2014; Abidi,2015; Fuerst \& Zettinig, 2015]. The founder's pre-firm knowledge is critical in providing the source of initial hierarchical knowledge-based interpersonal ties and also the technological and international impact of the firms' proactive or reactive behaviour as having an important role in establishing internationalization processes [Nordman \& Melen, 2008; Kuivalainen et al., 2012; Masango \& Marinova, 2014].

Orientations as one of the main-theme bands plays a criticial role at the stage of rapid internationalization and growth as a result of international market dynamics. This demonstrates why 24 articles which encompass $6.8 \%$ of the research have been taken into consideration within this framework. To summarize entrepreneurial orientation is a basic need for this type of acceleration in which behaviour is characterized by pro-activeness, innovativeness and risk-taking in a firm's pursuit of international opportunities [Sepulveda \& Gabrielsson, 2013], learning orientation is crucial for the attainment of knowledge to improve new behaviours, to encourage learning and increase humanresource capacity and to exploit the changes of the ongoing market [Jantunen et al., 2008; Kungwansupaphan \& Siengthai, 2014], strategic orientation is dependent on the country/market which they are entering, the related environmental conditions and also the entry mode of choice which is relevant to their strategy [Khavul et al., 2012; Efrat \& Shoham, 2013], market orientation provides information and the knowledge that firms seek in order to accomplish activities successfully in a transitional phase within new markets and additionally it is a base of influence for the international actors [Knight et al., 2004; Kocak \& Abimbola, 2009; Kim et al., 2011; Ripolles \& Blesa, 2012; Monferrer et al., 2015b], and global orientation is analogous with being adaptive within the arena of internationalization which will contribute positively to profitability simultaneously with regionalization. 
Entrepreneurial/managerial factors are another main-theme band and focuses ing on sub-themes such as entrepreneurial capital which is based on the founding of a team that creates a base for rapid learning and action capability [Federico et al., 2009; Loane et al., 2014; Munoz-Bullon et al., 2015]. Managerial characteristics are essential to sustain the internationalization stages by supporting a common set of behaviours and allocation of resources [Freeman \& Cavusgil, 2007; Loane et al., 2014; Ricard \& Saiyed, 2015; Gerschewski et al., 2015]. Intellectual Property has a role in becoming a global technology and knowledge-intensive entity but could also be a hindrance to a competitor's ability to leverage, therefore, it can also support the market and leverage knowledge [Mets et al., 2010]. 22 articles with a 6.2\% ratio constitutes a major base for those aforementioned factors.

Organizational issues as one of the main-themes bands consist of themes related to organization which exists separately compared to the known structures with a new setting and complex order [Yamakawa et al., 2008; Kocak \& Abimbola, 2009; Li et al., 2015b]. Under this main-theme band, sub-themes could be defined as organizational change which is an element affecting the strategy on a slippery base [McDougall \& Oviatt, 1996], business model effect displays some patterns but is not based on an accurate set of model types [Dunford, 2010; Hennart, 2014], strategic management is critical during the establishment period and requires strategic foresight if it is to be considered as a BG entity [Moen, 2002; Rialp et al., 2005; Gassmann \& Keupp, 2007; Hughes et al., 2010], the decision-making process has to be more personalized due to causation for effectuation [Nummela et al., 2014], transition costs could be greatly reduced by the collaboration and knowledge transfer of new markets [Shrader, 2001], corporate governance not only ensures effective monitoring of owner-managers, but defines what they do and how they do it in a highly globalized environment [Zahra, 2014] and social capital is the natural base for learning and knowledge [Prashantham \& Young, 2011; Prashantham et al., 2105]. 16 articles incorporating $4.5 \%$ of the research have been investigated in connection with these themes.

Innovativeness as a main-theme band is the ability of the firm to conceive new ways of thinking, processes and services but is also strongly tied to its capabilities; bo nded to a culture that supports all these factors [Knight \& Cavusgil, 2004; Hughes et al., 2010; Khavul et al., 2010a; Kim et al., 2011; Carvalho et al., 2014]. 11 articles with a 3.1\% ratio focused on this area. Business Functions as the last main-theme band of organizational themes consists of marketing strategies, HR management, finance which encompasses nine articles in total with $2.5 \%$ overall ratio.

\subsubsection{Sustainability themes}

The second thematic top-group is defined as sustainability themes which comprise the main-themes as follows: environmental factors, networks and alliances, growth and survival and locational determinants. The studies related to 
sustainability themes primarily consider environmental factors, the factors that affect the development and survival of BGs and also an examinination of networks and partnerships. Also the countries in which BGs are established and active are main factors in this band. 63 articles were investigated in the context of sustainability themes which represents $17.8 \%$ of the study pool.

As a main-theme band environmental factors include external and internal environmental factors [Efrat \& Shoham, 2011] and organization-environment fit [Khavul et al. 2010b] as sub-themes bands. In addition to general external environmental factors; psychic distance [Przybylska, 2013], governmental policy [Zahra, 2014], locational factors [Fernhaber et al., 2008], industry structure [Fernhaber et al., 2007], cultural influences [Zhang \& Dodgson, 2007], interorganizational imitation [Fernhaber \& Li, 2010] are the sub-themes that were discovered as relating to environmental factors.

The networks and alliances theme is another main-theme band which focuses on how BGs use networks to develop partnerships and alliances in international markets [Freeman et al., 2006]. These themes are related in their desire to improve sustainable relationships, examine topics such as networking [Tang, 2011], social capital [Presutti et al., 2007], collaboration [Shrader, 2001], connectors [Smith, 2012], and entrepreneurial networks [Vasilchenko \& Morrish, 2011]. Networks and alliances explore 7.9\% of the BG oriented studies and fulfill a significant gap in this area.

Although the financial situation is a crucial element several factors suggest that survival and growth, rather than profitability, is an important question in BG research [Mudambi \& Zahra, 2007]. In this respect the growth and survival main-theme band was considered to understand the factors that explain how BG firms survive in a highly competitive environment such as survival rates [Sapienza et al., 2006] and post entry growth [Sleuwaegen \& Onkelinx, 2014]. In total eleven articles generate $3.1 \%$ of the study pool.

Separate from environmentally related main-themes locational determinants are counted as a separate main-theme. The locational situation was seen as more advantageous when investigating the home country effect [Prashantham \& Birkinshaw, 2015], the host country effect or attractiveness [Cannone \& Ughetto, 2015] and the foreign market familiarity [Schwens \& Kabst, 2011] independently from environmental factors. In the context of locational determinant, six articles were $1.7 \%$ of the study pool.

\subsubsection{Internationalization themes}

The third thematic top-group internationalization themes have been categorized as three main-theme bands which are; internationalization $[A]$, internationalization [B] and others. In total 85 articles make up $23.4 \%$ of the studies that were considered in the analysis. As a result of the thematic analysis, patterns of internationalization, processes of internationalization and the antecedents of BGs' internationalization have arisen as a sub-theme band. 
The patterns of internationalization sub-theme band involve pathways, scope, scale and internationalization time [rapidity, speed] of BGs [Chetty et al., 2004; Hashai, 2011; Sui et al., 2012; Taylor \& Jack, 2013]. The internationalization experience of firms and mode of internationalization - direct modes or intermediate modes of international expansion are grouped under the process of internationalization sub-theme band [Chandra et al., 2012; Kalinic \& Forza, 2012; McAuley, 1999; Park \& Rhee, 2012; Pellegrino et al., 2015].

Internationalization $[\mathrm{A}]$ has been labelled separately as explaining the antecedents of BGs' internationalization which involves driving forces and strategies of early internationalization [Laanti et al., 2007; Holtbrugge \& Wessely, 2009; Baronchelli \& Cassia, 2014]. Internationalization [B] focuses on the entry mode choice [Melen \& Nordman, 2009; Satta \& Persico, 2015], international commitment [Nadkarni \& Perez, 2007; Zhou \& Wu, 2014], market entry strategies [Chun et al., 2014, Sinha et al., 2015], post entry behaviour [Johanson \& Martin, 2015] and barriers to the internationalization of BG firms [Kiss et al., 2013; Johanson \& Martin, 2015]. The final main-theme band for internationalization is named as 'Others'. This band covers the literature reviews [Park et al., 2015], conceptualization and theorizing studies [Rasmussen \& Tanev, 2015], definitions [Cesinger et al., 2012] and classification [Crick, 2009] studies of BGs/international new ventures, success stories regarding BG phenomenon [Gupta \& Shapiro, 2014] and interactions with international new ventures and MNEs [Prashantham \& Dhanaraj, 2015].

\subsubsection{Research themes}

The last thematic top-group is research themes which comprises $19.8 \%$ of all studies that have been included in the analysis. This theme group consistis of three main-theme bands. The first main-theme band has been named as comparative studies which investigates correlating BG studies between countries [Moen \& Servais, 2002; Loane \& Bell, 2006; Loane et al., 2007] which include those that compare BG firms and traditional firms [McDougall, 1989; Kalinic \& Forza, 2012].

In the second main-theme band - the regional main characteristics of BGs [Cabrol \& Nlemvo, 2009; Paul \& Gupta, 2014; Sui et al. 2012], the articles which attempt to determine the characteristics of $\mathrm{BG}$ firms have been taken into consideration. The lack of studies regarding country specifics could be result from the fact that conditions which stimulate the birth of BG firms in different regions are so diversified that they are inadvertently become an obstruction to the uncovering and analysis of the similarities and differences between different regions. As a result the increase of inquiries in several geographical locations plays a vital role in creating a strong base for comparison.

Technology-intensive BGs is a main-theme band which investigates the industries related to the $B G$ area and have been separated as a third main-theme band [Laanti et al., 2007; Hughes et al., 2010, Li et al., 2012]. Out of 70 research- 
ers 23 are focused on technology-intensive BGs whilst those remaining explore research themes. Therefore it is considered that there should be more studies executed in several different industries as BG firms are not only observed in technology intensive industries, but also exist in many traditional industries.

\subsection{Publication analysis $B G / I N V$ researches}

The numbers of articles that were published in WOS can be seen in Figure 2. The graph shows that the numbers of articles related to BG were capped at 18 years, just after the term BG was introduced and especially considering that a peak was reached in 2007 where an increase in studies took place. However, in the following years, the quantity of studies is inconsistent, the number of articles increased.

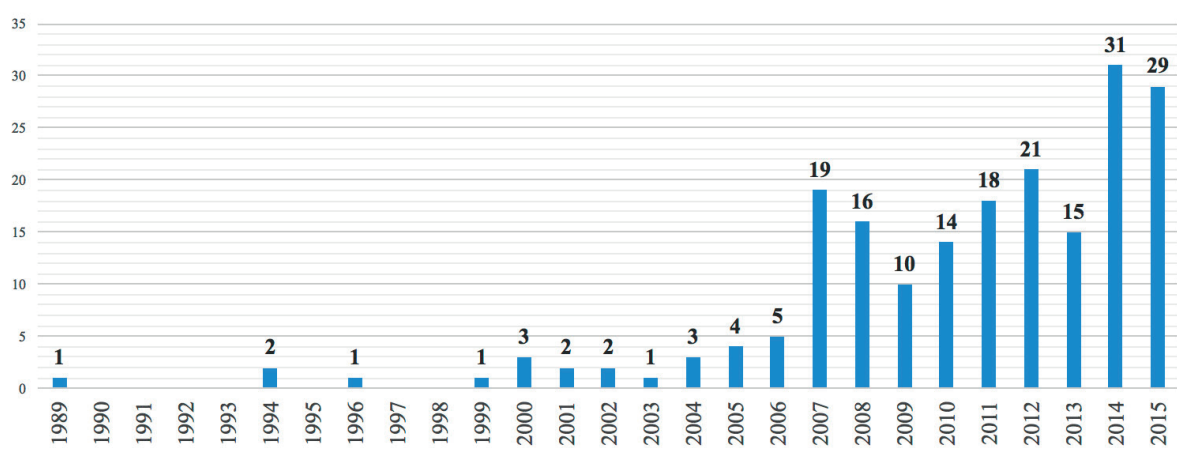

Figure 2. Number of articles relating to the subject of BG distributed between 1989-2015

Source: own compilation based on detailed research through Web of Science.

Between the years 1989 and 2015 the highest point was in 2014. These results could be explained as a consequence of the inability to explain the behaviour of international firms utilizing traditional internationalization models. It can be foreseen that the amount of studies will continue to increase due to the fact that BG model is an appealing area for the researcher as an alternative model to explain new behaviours in the international arena.

In Table 1 the number of articles are shown alongside the journal names and where published during this timeframe. The Journal of World Business has published the most articles relating to this area. The Journal of International Business Studies and the International Business Review are those which follow as.

Table 2 shows the list of the universities with the most publications which defines the name and numbers of the universities of the authors. Georgia State University has the highest number of author number which contributes to the BG area. 
Table 1. List of the top 10 most publishing journals about BG during years

\begin{tabular}{|c|c|c|c|c|c|c|c|c|c|c|c|c|c|c|c|c|c|c|c|}
\hline Name of the journal & 亏 & $\stackrel{\circ}{2}$ & Әे & 总 & હેડ & స్లి & Sి & ¿ి & 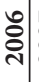 & 今ે & 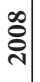 & ஓ্ণী & $\stackrel{0}{\circ}$ & 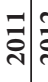 & 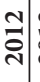 & 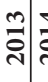 & 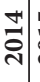 & in & స్ㅠㅇㅠ \\
\hline Journal of World Business & & & & & & & & & & 10 & 5 & & 1 & 12 & 2 & 12 & 2 & 1 & 23 \\
\hline Journal of International Business Studies & 1 & & & & & & 1 & 3 & 1 & 4 & 1 & 1 & 1 & 1 & 1 & & 1 & 3 & 19 \\
\hline International Business Review & & & & & & & & 1 & & 1 & 1 & 1 & 1 & 22 & 2 & 32 & 4 & 3 & 19 \\
\hline Journal of International Marketing & & & & 1 & 1 & 1 & 1 & & 1 & 1 & & & 2 & 13 & 3 & & 1 & & 13 \\
\hline Management International Review & & & & & & & & & & & & & & 12 & 2 & & 7 & 3 & 13 \\
\hline International Marketing Review & & & & & 1 & 1 & 1 & & 2 & & & 2 & 1 & & 2 & 2 & & & 11 \\
\hline Journal of Busines Venturing & & 1 & & & & & & & & & 1 & & 1 & & 1 & 1 & 1 & & 8 \\
\hline Entreprenuership Theory and Practice & & & & & & & & & & 1 & 1 & 1 & 1 & 1 & & & 1 & 1 & 7 \\
\hline European Journal of Int. Management & & & & & & & & & & & & 3 & & 1 & 1 & & & 1 & 6 \\
\hline International Small Business Journal & & & & & & & & & & & & & & 2 & & 2 & & 1 & 5 \\
\hline
\end{tabular}

Note. The number of published articles correlating to the subject included in Small Business Economics, International Entrepreneurship and Management Journal, European Management Journal is 4; Journal for East European Management Studies, Academy of Management Journal, Long Range Planning, Industrial Marketing Management, European Business Review, Journal of Business Research is 3; Management Decision, Global Strategy Journal, Technovation, European Journal of Marketing, Journal of Small Business Management, International Journal of Human Resource Management, Entrepreneurship and Regional Development, Transformations in Business \& Economics is 2; and various other journals issued 1 article at most.

Source: own compilation based on detailed research through Web of Science.

Table 2. List of universities with the most publications

\begin{tabular}{|l|c|}
\hline \multicolumn{1}{|c|}{ Name of the university } & Number of publishings \\
\hline Georgia State University & 11 \\
\hline Lappeenranta University of Technology & 10 \\
\hline Indiana University & 10 \\
\hline Aalto University & 9 \\
\hline University of Giessen & 8 \\
\hline
\end{tabular}

Note. The number of publications from the University of Ottava, University of Ulster, University of Texas at Arlington, Brock University, Norwegian University of Science and Technology is 7; University of Queensland, Universitat Jaume, University of Southern Denmark, Turku University, Sydney University is 6; Iowa State University, University of Texas, Jaume I University is 5; University of Vaasa, Stockholm School of Economics, Georgia Institute of Technology, Florida State University, Monash University, University of Waikato is 4 . As can be seen the most publications came from the researchers of Georgia State University.

Source: own compilation based on detailed research through Web of Science. 
The number of studies from researchers of various countries can be viewed in the Table 3. These countries have been defined according to the universities of the researchers.

Table 3. List of countries with the most publications according to researchers' institutions

\begin{tabular}{|c|c|c|c|c|c|c|c|c|c|c|c|c|c|c|c|c|c|c|c|c|c|}
\hline $\begin{array}{c}\text { Name of the } \\
\text { journal }\end{array}$ & $\stackrel{\circ}{2}$ & ริ & 2 & 亏े & ) & ఫ్రి & ฮิ & હ̊̊ & ఫ్ & 望 & ๖ి & હે & 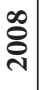 & ஓి & $\stackrel{0}{\circ}$ & $\bar{d}$ & $\underset{\sim}{\stackrel{\sim}{2}}$ & $\stackrel{n}{\stackrel{4}{\nu}}$ & J্ণ & ำ & 퐁 \\
\hline USA & 1 & 5 & 2 & & 7 & 2 & & 2 & 3 & 4 & 2 & 12 & 12 & 5 & 13 & 8 & 6 & 13 & 6 & 3 & 106 \\
\hline UK & & & & & & & & & & & 4 & 5 & 5 & 3 & 7 & 4 & 2 & & 12 & 3 & 45 \\
\hline Australia & & & & 1 & & 1 & & & & & 4 & 7 & 2 & & 6 & & 6 & 5 & 6 & 3 & 41 \\
\hline Finland & & & & & & & & & & & & 4 & 8 & & & 2 & 3 & 5 & 8 & 4 & 37 \\
\hline Spain & & & & & & & & & & 1 & & 1 & & 1 & 3 & 3 & 5 & 1 & 5 & 9 & 29 \\
\hline Canada & & & & & & & & & & & & 1 & 2 & & 1 & 3 & 9 & & 7 & 3 & 26 \\
\hline China & & & & & & & & & & & & 3 & & & 1 & 1 & 4 & & 3 & 8 & 20 \\
\hline Italy & & & & & & & & & & & & 5 & 1 & & & & 1 & & 6 & 6 & 19 \\
\hline Germany & & & & & & & & & & & & & 1 & 4 & & 8 & 1 & 3 & 1 & & 18 \\
\hline New Zealand & & & & & & & & & 2 & & 1 & & 2 & & & 2 & 1 & & 1 & 7 & 16 \\
\hline Sweden & & & & & & & & & & & & & 2 & 2 & 2 & & 1 & & 4 & 3 & 14 \\
\hline Denmark & & & & & & & 1 & & 2 & & & 2 & & & & & 2 & & 1 & 2 & 10 \\
\hline Israel & & & & & & & & & & & & & & & & 3 & 2 & 2 & 2 & & 9 \\
\hline Norway & & & & & & & 2 & & & & & 2 & 4 & & & & & & & & 8 \\
\hline Netherlands & & & & & & & & & & & & & 2 & & & & 2 & 1 & 2 & & 7 \\
\hline Ireland & & & & & & & & & & & & & 1 & & & 2 & 4 & & & & 7 \\
\hline France & & & & & & & & & & & & & & 2 & & & 1 & & & 3 & 6 \\
\hline South Korea & & & & & & & & & & & & & & & & & 2 & & & 3 & 5 \\
\hline
\end{tabular}

Source: own compilation based on detailed research through Web of Science.

The highest number was by researchers working in universities in the USA. The United Kingdom followed with 45 researchers with Australia close behind with 41 researchers. Finland, Spain and Canada are the other following countries. 


\section{Conclusions}

The term BG has become a trend topic in international business literature after it was first conceptualized in the early 1990s. All studies which are framed according to the aforementioned methodology between the years 1989 and 2015 have been mapped out and conceptualized to design a thematic analysis. Considered The studies in the English language were sourced from the Web of Science Core Collection. 198 articles were included in the study. All those articles have been classified according to their year of issue, journal, author, institution of researcher, country and focused subjects.

After the statistics were examined it could be concluded that 2007 was a critical year encompassing 19 articles which was four times more than the previous year. 31 were published in 2014 which was the highest level of publications however 2015 was comparable with 2014 which included 29 articles. After scanning all journals the one with the most publications is the Journal of World Business followed by the Journal of International Business Studies and the International Business Review. In addition to this McDougall (8 articles), Oviatt (6 articles), Prashantham (6 articles), Cavusgil (5 articles), Freeman (5 articles), Fernhaber (5 articles) and Zhou (5 articles) have made the biggest contribution to the field.

Classification according to the country of origin for the given universities is as follows; Georgia State University contributed the highest number of studies in the USA, followed by Lappeenranta University of Technology in Finland and Indiana University in the USA. The overall country origins of the most published studies include USA, UK and Australia, in that order.

When the articles were evaluated according to their type, out of 198 articles, 167 of them are empirical, 25 of them are conceptual and 6 of them are review studies. According to these results the highest number of studies are empirical.

As a result of the thematic analysis, four thematic top-groups (organizational, sustainability, internationalization, research), 17 main-theme and 49 subthemes bands were classified. Organizational themes with 138 articles (39\%) was set as the parameter of the study. Other thematic top-groups are the internationalization theme represented with 83 articles (23.4\%), sustainability themes with 63 articles (17.8\%) and research themes with 70 articles (19.8\%).

As many researchers have focused on organizational themes it is the largest top-theme group when compared to other groups. First of all it has to be understood that the organizational side of BGs is essential and it is important to explore the success factors of BGs. Therefore areas such as organizational capability (8.8\%) to identify which capabilities are effective for transformation into a BG firm, learning and knowledge (7.1\%) to identify the critical phases of behaviour in successful BGs, orientation $(6.8 \%)$ to create the necessary strategic vision for global market opportunities, entrepreneurial/managerial factors $(6.2 \%)$ to realize the necessary managerial characteristics, intellectual and 
entrepreneurial capital. These areas are still of great moment and BG is not an easy area for which to determine the basic principles under rapidly changing conditions. Also areas such as organizational issues (4.5\%), innovativeness (3.1\%) and business functions (2.5\%) are still in need of research and the results could be fruitful. In regards to future studies, finance and HR related research could be beneficial for newly emerging BG firms in order to use their resources effectively.

In internationalization themes as a top-group, process, pattern and antecedents of BG internationalization, market entry and entry mode (in total 13\%) has been seen as the most critical area. Nevertheless post entry behaviour $(1.1 \%)$ and barriers to internationalization $(0.8 \%)$ are the least examined areas. For further studies factors that could create barriers for international entries and elements for a successful entry could be explored especially when supported by real life examples. Accordingly the development of BGs could be boosted by studies about INV-MNE interaction, win-win style growth and development. In the sustainability themes as a top-group the efforts of BGs/INVs for joining networks and alliances is an intensely examined area (7.9\%). The lack of growth and survival related research has been observed in the context of environmental variables that BGs are facing in their achievement of sustainable competitive advantages. As many firms are disappearing as a result intense competition these studies are essential. Home and host country related studies are important and which have played a crucial role on the impact of BG internationalization. In the research themes the studies which display country comparisons, BGs and traditional firms are the main focus $(10.5 \%)$. The main regional characteristics of BGs $(2.8 \%)$ as a main-theme band was observed as an inadequate area. It is imperative that there be an increase in diversified studies which should be executed in several countries. As BG related studies are mainly focused on technology intensive sectors, checking other traditional industries is a necessity for a better overall understanding. Studies that can explain the steps in designing a BG firm could be a ground-breaking area.

The BG topic has already begun to open a new era for international business models as a result of integrated economies through accelerated communication and technological opportunities. It is not as it was before and firms which are designed smartly from the beginning could possibly open the doors to international markets and turn into a shining star. All traditional models are ready to be discredited as a result of the consequential shifts in paradigms. Theory should chase but also illuminate reality. That is why the BG area will incrementally expand as it is an intriguing mystery for those entrepreneurs who are seeking to capture competitive advantage by expanding in to international markets quickly. This study may be seen as an important glimpse into the future encompassing the overall possibilities for future inquiry and exploration. 


\section{References}

Bell, J., McNaughton, R. \& Young, S. (2001). Born-again global firms: an extension to the born global phenomenon. Journal of International Management, 7, 173-189.

Bilkey, J. W., \& Tesar, G. (1977). The export behavior of smaller-sized Wisconsin manufacturing firms. Journal of International Business Studies, 8, 93-98.

Cavusgil, S. T. (1980). On the internationalisation process of firms. European Research, 8(6), 273-281.

Cavusgil, S. T. (1994). A quiet revolution in Australian exporters. Marketing News, 28(11), 18.

Cavusgil, S. T., Knight, G. A., \& Riesenberger, J. R. (2008), International business - strategy, management, and the new realities. Upper Saddle River, NJ: Pearson Prentice Hal.

De Clercq, D., Sapienza, H. J., Yavuz, R. I., \& Zhou, L. (2012). Learning and knowledge in early internationalization research: past accomplishments and future directions. Journal of Business Venturing, 27(1), 143-165.

Fillis, I. (2001). Small firm internationalisation: an investigative survey and future research directions. Management Decision, 39(9), 767-783.

Gallego, Á., \& Casillas, J. C. (2014). Choice of markets for initial export activities: Differences between early and late exporters. International Business Review, 23(5), 1021-1033.

Hordes, M. W., Clancy, J. A., \& Baddaley, J. (1995). A primer for global start-ups. The Academy of Management Executive, 9(2), 7-11.

Johanson, J., \& Vahlne, J.-E. (1977). The internationalization process of the firm-A model of knowledge development and increasing foreign market commitments. Journal of International Business Studies, 8, 23-32.

Jones, M. V., Coviello, N., \& Tang, Y. K. (2011). International entrepreneurship research (1989-2009): a domain ontology and thematic analysis. Journal of business venturing, 26(6), 632-659.

Keupp, M. M., \& Gassmann, O. (2009). The past and the future of international entrepreneurship: a review and suggestions for developing the field. Journal of Management, 35(3), 600-633.

Kiss, A. N., Danis, W. M., \& Cavusgil, S. T. (2012). International entrepreneurship research in emerging economies: a critical review and research agenda. Journal of Business Venturing, 27(2), 266-290.

Knight, G. A. (1997). Emerging paradigm for international marketing: the born global firm, Doctoral dissertation. East Lansing: Michigan State University.

Knight, G. A. \& Cavusgil, S. T. (1996). The born global firm: a challenge to traditional internalization theory. Advances in International Marketing, 8, 11-26.

Knight, G. A., \& Cavusgil, S. T. (2004). Innovation, organizational capabilities, and the born-global firm. Journal of International Business Studies, 35(4), 334-334. doi: 10.1057/palgraves.jibs.8400096

Madsen, T. K., \& Servais, P. (1997). The internationalization of born globals: an evolutionary process?. International Business Review, 6(6), 561-583.

McAuley, A. (1999). Entrepreneurial instant exporters in the Scottish arts and crafts sector. Journal of International Marketing, 7(4), 67-82. 
McDougall, P., Phillips, S. S., \& Oviatt, B. M. (1994). Explaining the formation of international new ventures: the limits of theories from international business research. Journal of Business Venturing, 9(6), 469-487.

Oviatt, B. M., \& McDougall, P. (1994). Toward a theory of international new ventures, Journal of International Business Studies, 25(1), 45-64.

Oviatt, B. M., \& McDougall, P. (1995). Global startups: entrepreneurs on a worldwide stage. The Academy of Management Executive, 9(2), 30-43.

Oviatt, B. M., \& McDougall, P. (1997). Challenges for internationalization process theory: the case of international new ventures. Management International Review, $37(2), 85-99$.

Podsakoff, P. M., Mackenzie, S. B., Bachrach, D. G., \& Podsakoff, N. P. (2005). The influence of management journals in the 1980s and 1990s. Strategic Management Journal, 26(5), 473-488.

Preece, S. B., Miles, G., \& Baetz, M. C. (1999). Explaining the international intensity and global diversity of early-stage technology-based firms. Journal of Business Venturing, 14(3), 259-281.

Reid, S. D. (1981). The decision-maker and export entry and expansion. Journal of International Business Studies, 12(2), 101-112.

Rennie, M. W. (1993). Born Global. The McKinsey Quarterly, 4, 45-52.

Rialp, A., Rialp, J., \& Knight, G. A. (2005). The phenomenon of early internationalizing firms: what do we know after a decade (1993-2003) of scientific inquiry?. International business review, 14(2), 147-166.

Sapienza, H. J., Autio, E., George, G., \& Zahra, S. A. (2006). A capabilities perspective on the effects of early internationalization on firm survival and growth. Academy of Management Review, 31(4), 914-933.

Yeoh, P. L. (2000). Information acquisition activities: a study of global start-up exporting companies. Journal of International Marketing, 8(3), 36-60. 